\title{
Przewidywane rozwiązania przyszłościowe systemu zarządzania budynkiem
} Expected Future-oriented Solutions
in Building Management Systems

\begin{abstract}
Streszczenie
Systemy zarządzania budynkiem to część tematyki związanej z inteligentnymi domami, to zautomatyzowanie budynku polegające na połączeniu 3 komponentów: sensorów, urządzeń wykonawczych i jednostek obliczeniowych. Algorytmy sztucznej inteligencji będą mogły w przyszłości na bazie naszych zachowań oraz informacji z sensorów przewidzieć nasze potrzeby i samodzielnie określić działania niezbędne do ich realizacji.

To właśnie jest przejawem sztucznej inteligencji. Rozwijające się na coraz większą skalę algorytmy sztucznej inteligencji w obszarach związanych z przewidywaniem potrzeb i zachowań wskazują na taką właśnie drogę rozwoju również dla SzB. Sprzyjać temu będzie również możliwość porozumiewania się głosem z automatyka budynków, jako naturalna formą komunikacji z użytkownikiem. Powyższe obserwacje można przenieść na pole badań nad zachowaniami ludzkimi. Przewidywane jest bardzo przychylne przyjęcie sztucznej inteligencji w zastosowaniach komercyjnych. Konsekwencją tak rozumianej ewolucji jest spekulacja co do terminu kiedy myślenie abstrakcyjne będzie również w zasięgu sztucznej inteligencji.
\end{abstract}

\begin{abstract}
Building management systems are a part of the subject of smart homes, which are automated buildings based on a combination of three types of components: sensors, controlling devices and computation units. Artificial intelligence algorithms will be able to predict our needs based on our behaviours coupled with information gathered from sensors and determine the actions needed to satisfy them by themselves.

It is a manifestation of artificial intelligence. Artificial intelligence algorithms that are being developed on an increasingly large scale in areas associated with the prediction of needs and behaviours indicate a similar path of development for BMS as well. This will also be aided by the ability to verbally communicate with building automation systems, which is going to be a natural manner of communicating with the user. The observations listed above can be transferred to the field of studying human behaviours. The commercial application of artificial intelligence is predicted to be positively received. The consequences of evolution understood in this manner is speculation concerning the point in which abstract thinking will find itself within reach of artificial intelligence.
\end{abstract}

Słowa kluczowe: Smart Housing, dom inteligentny, Siri, Google Home, Alexa, aplikacje, chmura obliczeniowa, metoda logiki rozmytej, sztuczna inteligencja

Keywords: applications, cloud computing, fuzzy method, artificial intelligence

Tezą artykułu jest stwierdzenie, iż: jedynie wyobraźnia jest granicą dla integracji różnych światów. Teza będzie zilustrowana przykładem zmian koncepcji funkcjonowania programów służących do porozumiewania się, pomiędzy człowiekiem-użytkownikiem a SZB. Wybór przykładu dla zilustrowania problemu wynika $z$ zaawansowania prac nad uproszczeniem komunikacji i powszechnym docenianiem przez przemysł, takiej konieczności ewolucyjnej. Systemy zarządzania budynkiem to część tematyki, związanej z inteligentnymi domami. Na początek należy wyjaśnić podstawowe pojęcia: co to jest system zarządzania budynkiem i czym jest dom inteligentny? System zarządzania budynkiem ${ }^{1}$ (SZB) to zautomatyzowanie budynku polegające na połączeniu 3 komponentów: czujników czyli sensorów (temperatury, wilgotności, natężenia światła itd.), urządzeń wykonawczych
The article's thesis is the statement that the sole line between the integration of different worlds is imagination. The thesis will be illustrated with an example of the change of the concept of the functioning of software used to communicate between the human user and the BMS. The selection of the example for the purposes of illustrating the problem results from the advancement of efforts to simplify communication and the widespread appreciation of such an evolutionary necessity by the industrial sector. First, we should explain the basic concepts: what is a building management system and what is a smart home? A building management system $^{1}$ (BMS) is a form of building automation based on a combination of three types of components: sensors (temperature, humidity, light intensity sensors), controlling devices (elements that, for instance, turn light on or off, lower or increase temperature, etc.); management devices-com- 
(czyli czegoś co np. włącza światło, gasi światło, podnosi lub zmniejsza temperaturę itd.); urządzeń, które zarządzaja- jednostek obliczeniowych. Podstawową potrzebą, dla której wymyślono systemy zarządzania budynkiem, była chęć monitorowania parametrów stworzonej technologii i gromadzenie danych pomiarowych w celu dalszej analizy. Automatyka budynkowa pozwala na bardziej efektywne zarządzanie energią, a także podnosi komfort użytkowania. Istotnym aspektem jest również bezpieczeństwo. „Dom inteligentny" to nazwa budynku sterowanego SZB. „Dom inteligentny” w 2018r. nie jest jedynie testowanym prototypem ale stał się codziennością np. budownictwa jednorodzinnego. Również w Małopolsce istnieją ośrodki badawcze zajmujące się tą problematyką. Jednym z nich jest Klaster² Zrównoważonego Rozwoju z siedziba w Kokotowie pod Krakowem, w którym realizowano projekt „System zarządzania budynkiem". Na potrzeby niniejszej pracy zostały udostępnione wyniki powyższych prac, a wnioski pracy zostały zmodyfikowane w oparciu o praktyczne doświadczenia z wdrożeń systemu zarządzania budynkiem³. W SZB do wymiany danych służy system oparty o standard $\mathrm{KNX}^{4}$, który jest dobrym wyborem chociażby ze względu na bogaty wybór komponentów zarówno pod względem funkcjonalnym jak i wzorniczym. Standard KNX będący na rynku od ponad 20 lat, jest jedynym tak otwartym rozwiązaniem dającym szerokie możliwości integracji różnych rozwiązań ponad 400 producentów urządzeń pracujących w tym standardzie. Z perspektywy użytkownika daje to dodatkowe bezpieczeństwo $w$ aspekcie zachowania ciaggłości działania systemu w długiej perspektywie czasowej poprzez dostępność zamienników, co z kolei jest problematyczne w przypadku autorskich rozwiązań pojedynczych producentów. Rozwiązania nowatorskie- próby konkurencji nie dają takiej stabilności i pewności. Należy wykorzystać gotowe rozwiązania "asystentów” oferowanych przez Apple: Siri, Google: Google Home i Amazon: Alexa. Dają one szerokie możliwości dla użytkownika, od sprawdzenia pogody, czasu dojazdu, zamówienia taksówki, do w przyszłości coraz bardziej złożonych działań np. zarządzanie zakupami w domu na bazie naszych preferencii. Zarzadzanie domem jest $w$ tym przypadku jedną z domen obsługiwanych przez tego typu asystentów. Samodzielne i dedykowane rozwiazzania nie mają racji bytu - efektywnym rozwiązaniem jest współpraca z tymi $3 \mathrm{w} / \mathrm{w}$ rozwiązaniami ${ }^{5}$. $Z$ tego też powodu nie ma potrzeby pisania takich algorytmów na potrzeby firm „integratorów" ${ }^{\prime 6}$. Najbardziej kłopotliwe dla uzytkownika jest sterowanie- porozumiewanie się z automatyką. Po latach prób stwierdzono, że sterowanie głosem jest najwygodniejsze i najbardziej rozwojowe.

Obecnie do sterowania służą aplikacje mobilne, gdzie możemy wywołując odpowiednią funkcję, sterować wszystkimi urzadzeniami dostepnymi w systemie. To co jest wykorzystywane to sterowanie głosowe, jednakże obserwacje młodego pokolenia użytkowników urządzeń mobilnych wskazują na wzrost znaczenia komunikacji typu chat - za pomocą aplikacj typu Messenger. Komunikacja powinna być w takim przypad- putation units. The fundamental need for which building managemont systor the was the desire to monitor the parameters of dement data for further analysis. Building automatiotively, in addition to increasing comfort of use. Security is also an essential aspect. A "smart home" is the name of a building controlled by a BMS. I type, but has already become an everyday reality in, for instance, single-family housing construction. In Lesser Poland there are research centres that focus on this field as well. Klaster Zrównoważona Infrastruktura ${ }^{2}$ (Sustainable Infrastructure Cluster Krakow, and in which a "building in Kokotów nea Krakow, and in which a "building management sys
tem" project was carried out, is one of such centres. The results of the aforementioned work had been made available for the purposes of writing the article and the conclusions of the work wer modified based on practical experiences from the
application of building management systems $s^{3}$. The BMS uses a system based on the KNX standard to exchange information, which is a good choice because of the wide selection of components both in functional terms and design. The $\mathrm{KNX}^{4}$ standard which has been present on the market for over 20
years, is the only open solution giving broad years, is the only open solution giving broad pos-
sibilities of integrating various solutions by over 400 manufacturers of devices that operate using the standard. From a user's perspective this provides additional security in the aspect of preserving the continuity of the system's operation in the long
term through the availability of replacement parts which, in turn, is problematic in the case of origina solutions provided by individual manufacturers. Innovative solutions-attempts by the competition do not provide such stability and reliability. Available solutions in terms of "assistants" offered by Apple: Siri, Google: Google Home and Amazon of features to the user, ranging from checking the weather, travel time, ordering a taxi, to increasingly complex tasks that will be available in the future, such as managing a household's shopping on the this case one of the domains being mame is these types of assistants. There is no need for independent and dedicated solutions-cooperatio with the 3 aforementioned solutions is an effective solution. It is for this reason that there is no need to write such algorithms for use by "integrator"
companies". To a user, the most troublesome part $^{\circ}$. The is controlling-communicating with the automation systems. After years of trials it has been concluded that voice command is the most comfortable and has the most development potential. Control is currently performed through mobile
applications through which we can select an appropriate function and control all the devices avaiable in the system. They utilise voice commands, however, observations of the younger generation of mobile devices have indicated an increase of the significance of chat-type communication-usshould be bilateral in this case, which means the not only do we want something from our home, but our home can propose something, e.g. I left my
home in a car and received a message: "Should ku 2 kierunkowa tzn, nie tylko ja coś chcę od domu, ale również dom może cos mi proponować np. wyjechatem samochodem spod domu i dostaje komunikat: „Czy uzbroić alarm, bo chyba zapomniałeś" z gotowa podpowiedzia tak/nie. Dzie ki temu, dodatkowo tam gdzie algorytm jest niepewny działahia potwierdza je z użytkownikiem, co może stanowić dodatkowe wzorce do nauki dla algorytmów sztucznej inteligencji? Wybór sterowania głosem, a nie np. gestem-ruchem jak to jest w przypadku analizy obrazu, jest podyktowany łatwościa porozumienia się. Powstały systemy i urządzenia.

Jest to konsekwencja dwóch czynników: historycznegoewolucji człowieka dla którego głos jest najważniejszym instrumentem przekazu, oraz wspótczesnego- tatwiej zet wystarczajaca ilość próbek głosu i w celu opracowania algorytmu rozpoznawania głosu, przez urządzenie niż opracować moduł do analizy obrazu służący rozpoznawaniu gestów. Należy zaznaczyć, że rozpoznawanie głosu przez urządzenie; polega na przekazywaniu głosu do "chmury" (to nie telefon rozpoznaje głos), a tam na podstawie miliardów próbek głosu jest przez maszynę przetwarzany na sygnał dla programu.

Algorytmy rozpoznawania głosu nie stanowią już problemu, ta technologia jest już opanowana, a prace trwają nad lepsza interpretacją tego co zostało rozpoznane oraz inteligentna próbą zaspokojenia wyrażonych potrzeb. Firmy prowadząc zaawansowane prace nad sterowaniem głosem ${ }^{9}$ i sztuczn inteligencja, to nieprzypadkowo duże firmy: Google, Apple, Amazon. Jedynie one posiadają taka ilosć danych zbieranych od użytkowników, które służa do budowy efektywnego- bezawaryjnego algorytmu potrafiącego rozpoznawac mowe. Dostep do danych gromadzonych na serwerach stanowi o przewadze nad innymi ośrodkami badań nie posiadającymi takich zbiorów. Rozwój systemów sterowania głosem wymaga dostępu do danych gromadzonych na serwerach. W tym miejscu trzeba nadmienić, iż darmowe aplikacje są rozdawane jedynie pozornie, ponieważ ich cena to próbki danych o nas, którymi dzielimy się podczas używania oprogramowania. Stopień wyżej, biorąc pod uwage wygode, jest brak sterowania. To znaczy system odgadujący myśl właściciela. Niestety jest to niemożliwe dla obecnej techniki. Dlatego stwierdzono, że najbardziej zbliżony pod względem wygody będzie system uczący się. To znaczy wykazujący ce chy sztucznej inteligencji.

Ciekawym przykładem komercyjnego zastosowania „intelgentnego" urządzenia uczącego się zachowań użytkownika jest termostat Nest Google ${ }^{10}$ termostat, sterowanie ogrzewaniem, połączone z telefonem i uczące się zachowań użytkownika. Ładny gadżet łączący się z internetem (informacje nie a przetwarzane w urzadzeniu, lecz na serwerach Google). Ponadto obecnie już używane są programy uczące się. Algorytmy sztucznej inteligencji będą mogły w przyszłości na bazie naszych zachowań przewidzieć nasze plany np. zakupowe zachowania rutynowe itd. turn on the alarm? It appears you have forgotten to do so", with a default yes/no answer. Thanks to this, whenever the algorithm is unsure how to proceed, 1 asks for confirmation from the user for artificial intelligence algorithms? ${ }^{\text {. The selec- }}$ tion of voice command, instead of motion-gesture control, as it is in the case of image analysis, is dictated by the ease of communic
and devices have been developed.

is a consequen of two fed. one-the evolution of man, for whom speech is the most important instrument of expression, as well as a contemporary one-it is easier to gather sufficient amounts of voice samples in order to vice than to develop a module to analys images in order to recognise gestures. It should be noted that speech recognition by a device is performed by uploading voice samples into the "cloud" 8 (it is not the phone itself that recognises the voice), and vere, based on billions of voice samp vice

lem, as this technology has already been mastered and work is ongoing on improving the interpretation of what has been recognised along with a smart manner of satisfying the needs being expressed. If
is no coincidence that the companies that carry out advanced work on voice command devices ${ }^{9}$ and artificial intelligence are tech giants: Google, Apple and Amazon. Only they possess the amount of data gathered from users that can be used to construc an effective and reliable algorithm that can recog-
nise speech. Access to data gathered on servers constitutes an advantage over othered on servers tres that do not possess such collections. The development of voice-controlled systems requires access to data gathered on servers. It should be noted here that freeware applications are free in name that we share during our use of the software. A level higher, in terms of comfort, is no control at all. This means a system that predicts the thoughts of the user. Unfortunately, it is impossible for curren technology to do so. This is why it has been concluded that a self-learning system will be the clos-
est to it in terms of comfort. A system that has the qualities of an artificial intelligence.

One interesting example of the commercial application of a "smart" device that learns the behaviours of the user is the Google Nest ${ }^{10}$ therto a smartphone. It is a nice-looking gadget that connects to the Internet (the information is not processed within the device, but on Google's servers). Furthermore, machine learning programs are already in use. Artificial intelligence algorithms will be able to predict our plans, for instance, related
to shopping or to routine behaviours, etc., on the basis of our actions in the future.

This is a manifestation of artificial intelligence. Gadgets that can be conversed with (e.g. Alexa) and which can be integrated with installations of a smart building are already seeing commercial
application.

During the creation of an artificial intelligence, the
most difficult element is teaching the algorithm the proper reactions, instead of the writing of the algorithm itself'1. 
To właśnie jest przejaw sztucznej inteligencji. Już obecnie zastosowanie komercyine mają gadżety z którymi można rozmawiać (np. Alexa), również można je zintegrować $z$ instalacjami inteligentnego budynku.

Podczas konstruowania sztucznej inteligencji najtrudniejsze jest nauczenie algorytmu odpowiednich reakcji, a nie samo napisanie algorytmu11.

Systemy sterujące domem uczone są na bazie średnich zachowań populacji, a później dostosowywane do tego co sie dzieje w mniejszym obrębie. Również różnorodność tematyki jaką ma zajmować się sztuczna inteligencja jest ograniczona. Obecnie jest to inwencja i doświadczenie instalatorów przy stosowaniu klasycznych rozwiązań, natomiast w przyszłości bedą tu miały zastosowania algorytmy machine learning umożliwiające dostosowywanie się systemu do środowiska poprzez dynamiczną modyfikację, pozwalającą na poprawne działanie w zmiennych warunkach (robotyka, systemy sterowania, produkcji, analizy danych) ${ }^{12}$

Za 10-20 lat te urządzenie będą już nauczone wstępnie, a później moga być tuningowane ${ }^{13}$. Nie będzie konieczności programowania urzadzenia w 100\%, ono bedzie sie samo uczyć na podstawie danych zebranych przez operatora (w chmurze) i dodania do nich sygnałów z sensorów. Siri jest wbudowany w telefon (Apple), zaś system, Alexa (urządzenie Amazon) to połączenie serwera integracyjnego $w$ domu potrafiącego porozumieć się z urządzeniem. Rozpoznaje głos o przeciętnym natężeniu z 5-6m. System może również być użytkowany poprzez telefon z odpowiednią aplikacją, która zdalnie może sterować wszystkim co jest zasilane pradem. Bardzo prawdopodobny scenariusz rozwoju technik domowych przyszłości to właśnie systemy uczące się. Do realizacji zadań stojących przed samouczącymi się systemami próbowano zaadoptować system ekspercki, który ma z góry zdefiniowane reguły. Konkretny sygnał na wejściu daje konkretną odpowiedź (sygnał wyjście), oraz algorytmy fuzzy logic, który okazują się bardzo przydatna w zastosowaniach inżynierskich, gdzie klasyczna logika klasyfikująca jedynie według kryterium prawda/fałsz nie potrafi skutecznie poradzić sobie $z$ wieloma niejednoznacznościami i sprzecznościami. Metody logiki rozmytej wraz z algorytmami ewolucyjnymi i sieciami neuronowymi stanowia nowoczesne narzędzia do budowy inteligentnych systemów mających zdolności uogólniania wiedzy ${ }^{14}$

Przykładem jest zastosowanie algorytmu fuzzy logic zarzadzającego energią. Zadanie zdefiniowano następująco; ciepło powinno być zatrzymywane w przegrodzie W lecie jeżeli informacja ze stacji pogodowej na zewnątrz budynku, podaje, że jest odpowiednie naświetlenie. System porównując ilość luksów z kierunkiem oświetlenia domu, bryłą budynku i funkcją pomieszczeń zasuwają się rolety. Jeżeli ktoś jest w domu to rolety nie zasuwają się całkowicie, jedynie w $80 \%$. Jest to przykład algorytmu fuzzy logic, ponieważ w środku i na zewnątrz są czujki temperatury, których przybliżone parametry
Systems that control the home are taught on the base of the average common behaviours of the population and are then adapted to what is happenthat an artificial intelligence is meant to deal with is also limited. It is currently ness and experience of those who handle the installation when using classical solutions, however, machine learning algorithms will be applied in the future, enabling the systems to adapt to the envipossible for them to work properly under changing conditions (robotics, control, manufacturing data analysis systems) 12.

In 10 to 20 years' time these devices will go through initial learning, with the possibility of later tuning it will learn by itself on the basis of data gathered by the operator (in the cloud) and adding signals from its sensors. Siri is incorporated into a smartphone (Apple), while the Alexa system (an Amazon device) is linked with a home integration server tha
can communicate with devices. It can recognise can communicate with devices. It can recognise
a voice of average intensity from a distance of 5 to 6 metres. The system can also be used by a smartphone with an appropriate application that is able
to remotely control anything that is powered by to remotely control anything that is powered by
electricity. Self-learning machines are a very probable scenario of the development of home technoan expert-based system, which has predefine rules, to perform the tasks that are set before selflearning machines. A specific entry signal provides a specific answer (output signal), in addition to the use of fuzzy logic algorithms, which are highly use-
ful in engineering-related applications, where classical logic that classifies reality solely on the basis of true/false criteria cannot effectively deal with many contradictions and ambiguities. Fuzzy logicbased methods along with evolutionary algorithm the creation of intelligent systems that have the pability to generalise knowledge ${ }^{14}$.

One example is the use of a fuzzy logic algorithm to manage energy. The task was defined as follows: heat should be kept in a partition. During summer, ing states that there is appropriate illumination The system compares the amount of luxes, the direction from which the building is being illuminated the massing of the building and the function of its interior spaces and operates window blinds accordingly. If there is someone inside, the blinds will
not lower completely, but only to $80 \%$. This is an example of a fuzzy logic algorithm, because there are temperature sensors both inside and outside, and whose approximate parameters are being taken into consideration. The algorithm presented above has been developed as a solution on the ba-

At present, algorithms need to be devised on the basis of a programmer/home user's knowledge
and later modified for the end user, with the software being only as good as its programmer's knowledge. Artificial intelligence-machine inteligence-will have the system learning the user's
behaviours as effectively as its algorithms allow it to and as long as it is necessary. Initially, a developing system will surely be prone to making errors. The mimicking of living organisms, e.g. the ner- są brane pod uwagę. Algorytm powyższy powstał jako rozwiązanie na bazie programów Open Source

Obecnie algorytmy trzeba wymyśleć, bazując na wiedzy programisty-użytkownika domu a później zmodyfikować dla docelowego użytkownika, w takim przypadku program bedzie tak doskonały jak wiedza programisty. Sztuczna inteligencja - inteligencja maszynowa - system będzie się uczył zachowań użytkownika, tak dobrze jak dobre będą algorytmy i tak długo, jak to będzie wymagane. Początkowo z pewnościa system rozwijający się będzie narażony na pomyłki. Ciekawa ścieżka rozwoju może stać się naśladowanie organizmów żywych np. układu nerwowego. Sieci neuronowe, to stworzenie takiej struktu neuronowa w mózgu Sieci neuronowe to wynalazek z lat 5060 -tych $X X$ wieku' ${ }^{16}$. Przypomina działanie algorytmu symulującego zachowanie neuronów w mózgu. W najprostszym modelu neurony są połączone ze sobą, a każdemu połączeniu jest przyporządkowana waga. Uczenie się sieci, polega na doborze odpowiedniej wagi, to znaczy wartości liczbowej, której wartość zależy od modelu i wzorców uczących. W tego typu rozwiazzaniach skutecznosc dziatania jest zależna od sposobu doboru sieci neuronowej oraz zastosowanego algorytmu oraz wzorców uczących.

System uczący się musi wiedzieć, które sygnały są istotne które nie. Wtedy po jakimś czasie nauczy się je rozpoznawać. Przykładem nieistotnej informacji dla algorytmu może być: drzwi w pokoju nie są zamykane kiedy pada deszcz, a istotnej- okna są zamykane.

Snując rozważania nad przyszłością należy zadać pytanie: jak bẹdzie przyjmowana przez ludzi jeszcze większa niż obecnie ingerencja w prywatność? A tak stanie sie na pewno, co można stwierdzić obserwujac ewolucje automatyzacji domów. Można tu powołać się na autora Yuval Noah Harari i przypadki opisane w książce „Homo Deus: A Brief History of Tomorrow" (książka jeszcze nie jest wdana w języku polskim), oraz na obserwacje wskazujące jak bardzo osobistymi informacjam dzielą się ludzie na portalach społecznościowych. W rezultacie można oczekiwać, że przyjecie beedzie bardzo przychylne. Jesteśmy w stanie oddać bardzo dużo samostanowienia w zamian za wygodę i poczucie sprawowania władzy nad urządzeniami.

Sądzę że to wynik lenistwa i konformizmu. Śmiem nawe twierdzić że im słabszy charakter i umysł tym większe pożądanie mechanicznego "niewolnika”. W tym miejscu chciałbym przypomniec na przestrogę legendę o praskim Golemie, która jako żywo pasuje do inteligentnej maszyny - asystenta, którego pożąda człowiek rekompensujący sobie w ten sposób kompleksy i niskie poczucie własnej wartości.

Podsumowanie: Jak zostało stwierdzone na powyższych przykładach, integracja automatów z oprogramowaniem rozwija się w kierunku produktu sprawdzonego komercyjnie. Systemy uczace się z założenia musza być rozwojowe, więc można pokusić się o stwierdzenie, iż wyobrażnia autorów vous system, can prove to become an interesting path of development. Neural networks form mathematical structures which operate similarly to the works are an invention of the $1950^{\prime}$ s and $1960^{\prime} \mathrm{s}^{16}$. It resembles the work of an algorithm that simulates the behaviour of neurons within the brain. In the simplest models, neurons are connected with each other and each connection is assigned
a weight. The network's learning is based on selecting the appropriate weight, which is a numercal value that depends on the model and learning patterns. In these types of solutions the efectiveness of performance is dependent on the method
of the selection of the neural network and the adopted algorithm and learning pattern

A self-learning system must know which signals
are of significance and which are not. Then, after are of significance and which are not. Then, after
a time, it will learn to identify them. One example of information that is insignificant to an algorithm can be that a room's doors are not closed when rain is falling, while a significant one is that windows are.
When reflecting on the future we should ask the question: how will a greater invasion of individua privacy be received? This will surely be the case as it can be seen when observing the evolution of home automation. Here we can mention the au ther Yuval Noah Harari and the cases described in row" (the book has not been published in Polish yet as of the time of this writing) and observations indicating just how personal is the information that people share on social media. As a result we can expect that the reception will be very enthusiastic. determination in exchange for comfort and a feeling of control over devices.

I am of the opinion that it is a result of laziness and conformity. I would even dare to say that the weakdesire for a mechanical "slave". Here greater their to remind the reader of the legend of the Golem of Prague as a word of warning, as it perfectly fits as an analogy to the intelligent machine-assistant, that is desired by man as compensation for his insecurities and low self-esteem.

Conclusion: As it has already been stated on the gration of automatons with software is developing in the direction of a commercially-proven product. Machine learning systems, by definition, must develop, which means that we can risk making the statement that the imagination of authors can be future. In this field the line between worlds disappears. It means that the thesis was too carefully formulated, for not only is imagination not the final frontier, it can even become "stimulated" by artificial organisms, which will surely one day be
created. We can only speculate when will abstract thinking and such is necessary for imaginationcome within reach of artificial intelligence. Two words should be added to the sentence of the hesis: "At present" imag to thion is the sole line beween the integration of different worlds.

ENDNOTES

A building automation system (BMS) or BMS-Building Automation is a system of managing a building's automated
control systems, especially in a smart building. The task of 
może w przyszłości być wspomaganą sztuczną (nieożywioną) wyobraznią. Na tym polu zanika granica pomiędzy swiatami. To znaczy, ze teza byta zbyt ostroznie postawiona, bo nie tylpodkrecana" przez sztuczne organizmy, które z pewnościa kiedyś powstaną. Można tylko spekulować kiedy myślenie abstrakcyjne- a takie jest konieczne dla wyobraźni- będzie również w zasięgu szztucznej inteligencji. Należałoby dodać do zdania - tezy pojedyncze słowo: „Obecnie” jedynie wyobraźnia jest granicą dla integracji różnych światów.

PRZYPISY

ISystem zarzadzania budynkiem (ang. Building Management System) BMS lub
Automatyka budynkowa BMS - system zarzadzania systemami automatycznego

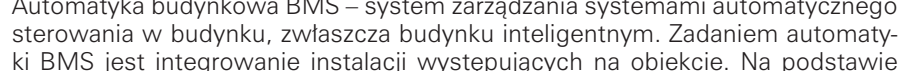

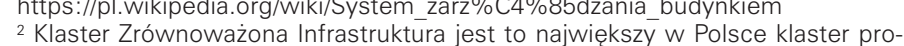
pagujacy i wdrazajacy dostepne cenowo energooszzzedne technologie budow-
lane, od 2016 uznany przzz Ministerstwo Rozwoju jako Krajowy Klaster KluczoWy. W jego skład wchodzi ok. 100 podmiotów, w tym najwieksze krakowskie
uczelnie jak: AGH, PK, UJ. Czlonkami klastra sa również miasta: Niepotomice Stomniki i i Piastów. Nadrzednym celem wspótpracy jest promocja naiwyższej
efektywności energetycznej w budownictwie. Na podstawie materiatów Polska efektywności energetycznej w budownictwie. Na podstawie materialow Polska
Agencja Rozwoju Przedsiebiorczości:

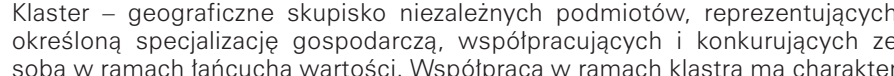

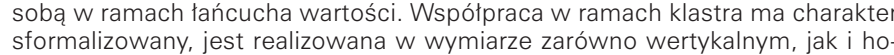
ryzontalnym i jest ukierunkowana na osiagniecie zatozonych wspónnych celów.
Klaster stanowi zrródto korzyści i tworzy nowa wartość dla wszystkich typów podmiotón uczestniczacych $w$ klastrze, takich jak przedsiebiorstwa, uczelnie i
inne jednostki naukowe, instytucje otoczenia biznesu, administracię publiczrna oraz pozostate organizacje wspierajace. Na podstawie aktualnego opisu Kla-
stra Zrównoważona Infrastruktura udostepnionego przez Pania Koordynator Irenę Eobocka:
${ }_{3}$ Na podstawie informacii udostepnionych przez firmę integracyina , Smart Ho-

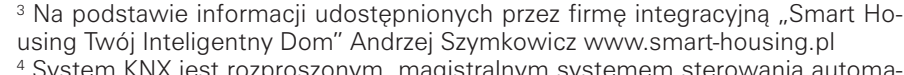
Aplikacji do zarzadzania budynkiem wraz z dedykowanymi urzadzeniami KNX
(Standard KONNEX / KNX instalacia elektryczna nowei generacii - umożliwia wspbilna komunikacje pomieddy ws wystskimi odbiornikami energii elektryycznej
w budynku) do monitorowania budynków pozwala w tatwy sposób sterować praca budynku z każdego miejsca na kuli ziemskiej. Na podstawie Wprowadze-

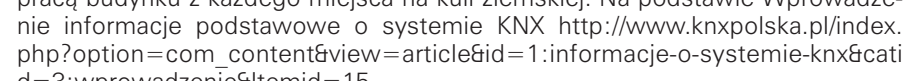

$5 \mathrm{Na}$ podstawie informacji udostepnionych przez firme integracyina, Smart Ho-
using Twój Inteligentny Dom" Andrzej Szymkowicz www.smart-housing.pl

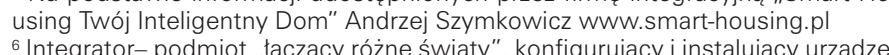
"Integrator- podmiou, ilackacy
nia automatyki w budynku.

"Na podstawie informacil udostepnionych przez firme integracyina , .Smart Ho ${ }_{8}^{8}$ Chmura obliczeniowa (również przetwarzanie $w$ chmurze, ang. cloud com ting) - model przetwarzania danych oparty na uìytkowaniu ustug dostarczonych ustuga (dająca wartość dodana użytkownikowi) oferowana przez dane oprogra mowanie (oraz konieczną infrastrukturę). Kwestią czasu jest dojście do szczytu nym) na serwer, a u uzuytkownika instalaccia ciennkiego klienta, majacego tylko in terfejsy komunikacji z obstugującą go osoba. Na podstawie https://pl.wikipedia. Org//iki/Chmura obliczeniowa
g Text to speech-Synteza mowy - dziat przetwarzania mowy polegajacy na me-

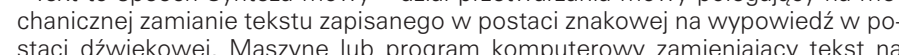
staci díwiekokowej. Maszyne lub program komputerowy zamieniajacy tekst na
mowe określa się mianem syntezatora mowyl algorytm musi najpierw rrozumieć co się mówi, im więcej próbek „więcej ludzi gada do tego urządzenia". na podstawie,a.............
10 Termostaty nest w cenie 279, Program Nest Learning Thermostat sam się programuje i automatycznie pomaga oszczedzac energie. Mozina zdalnie kon-
trolować system za pomoca telefonu, tabletu lub komputera. https://nest.com trolować system za pomocą telefonu, tabletu lub komputera. https://nest.com/
uk? from-chooser=true 11 Yuval Noah Harari w ni

History of Tomorrow" - twierdzi, że rozwój techniczny bedzie ukierunkowany na

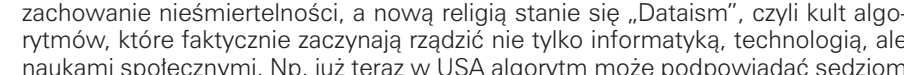

BMS automatics is the integration of installations that a bu zarz\%c4 4 ( ${ }_{2}^{2}$ Klaster Zrównoważona Infrastruktura (Sustainable Infrastructure Cluster in English-transl. note) is the largest cluste
in Poland that propagates and applies affordable energy-etficient construction technologiess and that has been recogn
sed as a Key National Cluster by the Ministry of Develoomen

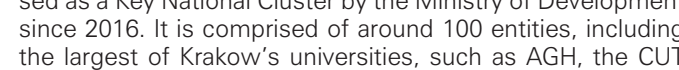
and the JU. The cities of Niepotomice, Stomniki and Piastów
are also members of the cluster. The overarching goal of cooperation as a part of the cluster is the promotion of the highest possible energy efficieincy in building construction.
Based on materials of the Polish Agency for the Deve lopment of Entrepreneurship
Cluster-a geographic grouping of independent entities ting and competing with each other within a chain of values. Cooperation as a part of the cluster has a formalised being directed at achieving predetermined common gaols.
A cluster constitutes a source of benefits and creates new A cluster constitutes a source of benefits and creates new
value for all types of entities participating in the cluster, such value for all types of entities participating in the cluster, subh
as businesses, universities and other scientific facilities, bu-
siness environment institututions, public administration an siness environment institutions, pubicic administrition and
other support organisations. Based on the current description of Klaster Zrównoważona
Infrastsruktura made available by Coordinator rena tobocka Infrastsruktura made available by Coordinator Irena Lobocka
${ }^{3}$ Based on information provided by the „Smart Housing Two Inteligentny Dom" Andrzej Szymkowicz integration compa
Inten ny, www.smart-housing.pl
4 The KNX system is a distributed hub system for controlling aplication, along with dedicaticated KNZ devines mithe KNONEX
KNX new generation electric installation enables mutuKNX new generation electric installation enables mutu-
al communication between all receivers of electric power al communication between all receivers of electric power
within a building) for the monitoring of a building makes it possible to easily control a building from any place around
the globe Based on Introduction - basic information about the KNX sy-

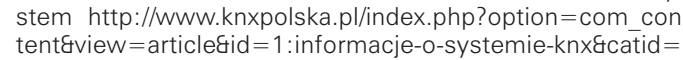

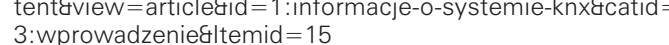
5: Warsod on informatition provided by ,Smart Housing Twój
Inteligentny Dom" Andrzej Szymkowicz integration company Inteligentny Dom Andzej Szymkowicz megration company
www.smarthousing.pl 6 Integrator-an entity that "connects different worlds",
configures and installs building automation devices within a building.
7 Baseg 'Based on information provided by "Smart Housing Two
Inteligentny Dom" Andrzej Szymkowicz integration compan

8 Cloud computing-a model of data processing based on
making of services available by a provider (an internal department or an external organisation). The cloud is a service (which
provides added value to the user) being offered by given soft ware (and the associated infrastructure). It is only a matter of time before the peak of virtualisation is reached-transferring all software (along with operating systems) to a server, with
the user only having to install a light client possessing only the interface necessara to communicate with the user.
Based on https:///pl.wikipipedia. org (wiki//Chmura_obliczeniowa ${ }_{9}^{9}$ Text to speech-a form of voice synthesising based on the mechanical conversion of text in the form of written characters
to speech in the form of sound. The machine or computer softWare converting text to speech is called a voice synthesiser. The
alorithm must first understand what is being said, so more samples are gathered when "more people talk to the device". Based on

Nest Learning Thermostat software programs itself and automatically helps to conserve energy, It can be remotely
controlled through a smartphone, tablet or a PC https://nest 11 Yual Noah Harari in his book Homo Deus: A Brief $H$ "Yuval Noah Harari in his book, Homo Deus: A Brief History
of Tomorrow", which has not yet become avaliable in Poland claimed that technological develooment will be directed to-
wards the achievement and preservation of immortality with "Dataism", a cult of algorithmns, which are starting to to ryle no "Only IT, technology and the social sciences, becoming a new religion. For instance, right now in the United States an algo-
rithm can suggest to a iudge a verdict concerning p ar of course this is a little inhuman, but it has been observed tha
Wyrok dotyczacy warunkowego zwolinienia. Oczywiscie to troszkę nieludznee, alesze dla spoteczeństwa Program trafniei imybiera osadzonych do waru kowego zwolnienia. Okazuje sie ze popethiaja pózíniej mniej przestepstw.
Bedziemy zatem żyli w swiecie algorytmów. I bedzie to swiat sprawiedliwy

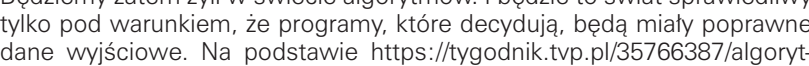

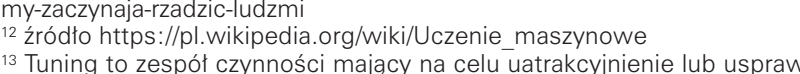

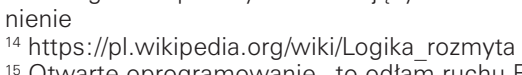

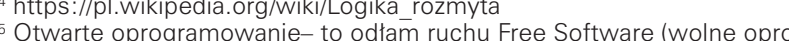
gramowaniel), ktorego conelem jost istrinienie swuobodnego dostepu do opro(a)

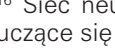

LITERATURA

[1] Harari Yuval Noah, Homo Deus A Brief History of Tomorrow, Vintage
Publishing 2017, ISBN13 (EAN): 7781784703936

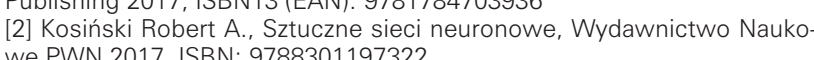

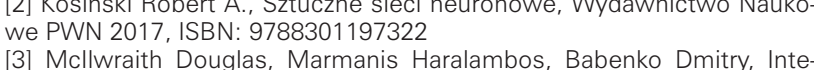

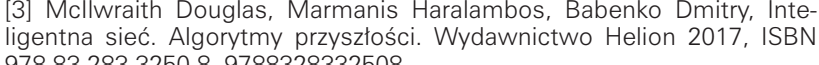
4] O'Driscoll Gerard, Essential Guide to Smart Home Automation Safety 5] Smart Home Automation Essential Guides, Createspace Independe ub, 2015, ISBN 150870127X, 9781508701279 16] O'Driscoll Gerard, Essential Guide to Samsung Smartthings Smar
Home Automation System: A Practical Guide to on How to Use Smart things Home Automation in Your Everyday Life. Home Automation Essen-
tial Guides, Createspace Independent Publishing Plattorm, 2015, ISBN tial Guides, CreateSpace Independent Publishing Plattorm, 2015, ISBN
1522998837, 97815222998839 [77 Rasshrk Sebastian, Python. Uczenie maszynowe, Helion 2017, ISBN
9788328336131 verdicts created by algorithms are more effective for society. A prothey commit less crime later on. We will thus live in a world of algorithms. And it will be a just world only under the condition that the
programs that make the decisions will have appropriate input data. programs that make the decisions will have appropriate innut data.
Based on https://tygodnik.tvp.p//35766387/algorytmy-zaczynaja-zadzic-ludzmi

Source: $\mathrm{h}$ htps:///pl. wikipedia.org//wiki/Uczenie_maszynowe
Tuning is a set of procedures meant to make something more

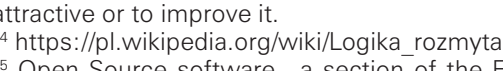

Open Source software-a a section of the ree Software movepants.
${ }^{16} \mathrm{Neural}$ networks, machine learning, deep machine learning - ma16 Neural networks,
chines that learn

BIBLIOGRAPHY

11] Harari Yuval Noah, Homo Deus A Brief History of Tomorrow, Vintage Publishing 2017, ISBN13 (EAN): 9781784703936
[2] Kosiński Robert A., Sztuczne sieci neuronowe, Wydawnictwo Naukowe PWN 2017, ISBN: 9788301197322

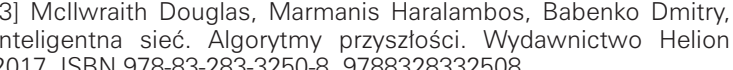

Safety \& Security. Use Home Automation to Increase Your Families

5) Smart Home Automation Essential Guides, Createspace Inde[6] O'D Driscoll Gerard, Essential Guide to Samsung Smarthings
Smart Home Automation System: A Practical Guide to on How to Use Smartthings Home Automation in Your Everyday Life. Home
Automation Essential Guides, CreateSpace Independent PublisAutomation Essential Guides, CreateSpace Independent Publis-
hing Plattorm, 2015, ISBN 1522998837, 978152299839 I7] Pastchka S 20bastian, Python. Uczenie maszynowe, Helion 2017.
ISBN 9788328336131 